College of Veterinary Medicine and Animal Production,

Khartoum North Sudan University of Science and Technology, Sudan.

\title{
RENAL FUNCTION OVER THREE 8-HOUR PERIODS IN HEALTHY SUDANESE NUBIAN GOATS
}

(With 4 Tables)

By

\author{
RANDA A.B.; SHADIA A. OMER and O.S. ALI
}

(Received at 16/9/2008)

\section{SUMMARY}

Renal function was investigated in 10 adult Sudanese Nubian goats (>2years old) by estimating the urine volume and constituents of each animal at $8 \mathrm{~h}$ intervals for $96 \mathrm{~h}$. Urine volume, urine flow rate, $\mathrm{pH}$, specific gravity, endogenous creatinine and urea clearance, urine concentration of urea, uric acid, total protein, and total excretory rate of proteins and electrolytes, were measured using standard methods. Blood serum constituents of the pervious chemicals were also estimated. Only urine outflow rate, urine urea concentration and uric acid as well as urea clearance differed significantly with time. These findings were discussed in relation to the renal function of goats and other ruminants.

Key words: Renal function, Sudanese Nubian Goats.

\section{INTRODUCTION}

The mammalian kidney plays a key role in the maintenance of the body internal environment. The renal function did not show any significant variation when tested at different urine collection periods, in dairy cattle (Fleming, et al., 1991) and in sheep (Garry, et al., 1991). In the Sudan Nubian goats are considered important household dairy animals which contribute to the nutrition (milk in particular) and economy of many families. The average milk yield of a Nubian goat ranges between 1.5-2 Kg per day. Information concerning renal function in normal Nubian goats seems to be limited. So this work was designed to measure urinary indices of renal function over three eight hour periods in healthy Sudanese Nubian goats. 


\section{MATERIALS and METHODS}

This study was conducted in November 2003.

\section{Animals:}

Ten apparently healthy non-pregnant and non-lactating Nubian goats were used. The animals were over 2 years of age with an average body weight of $22.5 \mathrm{~kg}$. They were dosed against both internal and external parasites, and kept in well ventilated pens at the Farm of the College of Veterinary Medicine and Animal Production Khartoum North. They were maintained on alfalfa hay adlibitum with free access to water. The goats were allowed an adaptation period of three weeks before the start of the experimental protocol.

Sample collection: Urine and blood samples were collected from each goat at $8 \mathrm{~h}$ intervals over a 96 hours period. A modified catheter with a plastic urine collection bag was used for urine collection. The urine catheter was introduced aseptically, after the vulva and the perennial region had been cleaned. The bladder was emptied and then rinsed with sterile distilled water. The urine collection bag was kept secure in a clean cloth bag. Each animal had been subjected to the urine collection procedure 3 times before the actual collection started. The daily collection periods were named: first $(7 \mathrm{am}-3 \mathrm{pm})$, second $(3 \mathrm{pm}-11$ $\mathrm{pm})$ and third collection periods (11 pm $-7 \mathrm{am})$.

Blood was collected with the aid of a fixed jugular vein catheter at mid time of each urine collection period. Serum was harvested and stored at $-20{ }^{\circ} \mathrm{C}$ until used.

\section{Physical properties of urine:}

Urine volume for each animal at each period was determined by a glass measuring cylinder. The urine $\mathrm{pH}$ and specific gravity were determined by a $\mathrm{pH}$ meter (Jenco Electronics USA) and a refractometer (Cambridge Instruments inc, USA) respectively.

\section{Chemical analysis of blood serum and urine were performed as follows:}

$\mathrm{Na}$ and K were measured by flame photometry (Wooton, 1974). $\mathrm{Ca}, \mathrm{P}, \mathrm{Cl}$, and $\mathrm{Mg}$ using standard procedure (Trinder (1960), Varley (1967), Vogel (1982), and Norbert (1982) ) respectively. Colorimetric method was adopted for the determination of Total protein, creatinine, urea and uric acid was determined by colorimetric method, using commercial test-kits (Linear Chemicals Ltd.Spain). 


\section{Calculations:}

\section{Endogenous creatinine and urea clearance:}

Endogenous creatinine clearance was calculated using the following equation (Guyton and Hall, 2000):

$\mathrm{CL}_{\mathrm{CR}}=\left(\mathrm{U}_{\mathrm{CR}} \times \mathrm{U}_{\mathrm{vol}} / \mathrm{S}_{\mathrm{CR}}\right) / \mathrm{kg}$ of BW/T.

Where $\mathrm{CL}_{\mathrm{CR}}=$ Endogenous creatinine clearance

$\mathrm{U}_{\mathrm{CR}}$ and $\mathrm{S}_{\mathrm{CR}}=$ urine and serum concentration of creatinine respectively.

$\mathrm{U}_{\mathrm{vol}}=$ urine volume in milliliters.

$\mathrm{Kg}$ of $\mathrm{BW}=$ body weight in kilograms.

$\mathrm{T}=$ time (hour).

The same procedure was followed for determination of urea clearance.

Electrolytes excretion rates were calculated, for a substance $\mathrm{Y}$, as follows:

$\mathrm{TE}_{\mathrm{Y}}=\left(\mathrm{U}_{\mathrm{Y}} \times \mathrm{U}_{\mathrm{vol}}\right) / \mathrm{kg}$ of BW.

$\mathrm{U}_{\mathrm{Y}}=$ Electrolyte level in urine.

$\mathrm{TE}_{\mathrm{Y}}=$ the total urinary excretion rate of $\mathrm{Y}$, which was expressed as millimol or milligrams, depending on the initial unit of measurement for the electrolyte (Bonsen and Toussky, 1945).

\section{Urine flow rate:}

Flow rate $=$ urine volume/time in hours/ body weight (Guyton and Hall, 2000).

\section{Statistical Analysis:}

The main effect was the time of collection. Statistical analysis of the obtained data among the different periods was performed by analysis of variance as described by Gomez and Gomez (1984). The results are given as the means \pm standard deviation.

\section{RESULTS}

No abnormal clinical signs were observed during the course of the study. The animals did not show any signs of pain, restless or discomfort during or after catheterization. All the animals were well adapted to the experimental protocol and remained in good condition to the end of the study.

The specific gravity, and $\mathrm{pH}$ did not varied among the periods. Significant variations $(\mathrm{P}<0.01)$ were observed with time for urine volume and flow rate (Table 1). Although a variation in the urine $\mathrm{Na}$ concentration was observed among the periods, its total excretory rate did not changed (Tables 2 and 3). Creatinine clearance, urine protein concentration and the total protein excretory rate remained stable with time, while urea clearance, urine urea and uric acid concentrations varied significantly (Table 4). 
Table 1: Effect of the time on some urine physical properties.

\begin{tabular}{|c|c|c|c|c|}
\hline Periods & $\mathrm{pH}$ & SPG & $\operatorname{Vol}(\mathrm{ml})$ & $\begin{array}{l}\text { Flow rate } \\
\mathrm{ml} / \mathrm{kg} / \mathrm{h}\end{array}$ \\
\hline $1^{\mathrm{st}}$ & $8.48 \pm 0.29^{\mathrm{a}}$ & $1.031 \pm 0.004^{\mathrm{a}}$ & $278.75 \pm 61.06^{\mathrm{b}}$ & $1.55 \pm 0.34^{\mathrm{b}}$ \\
\hline $2^{\text {nd }}$ & $8.51 \pm 0.27^{\mathrm{a}}$ & $1.031 \pm 0.007^{\mathrm{a}}$ & $249.9 \pm 55.82^{\mathrm{b}}$ & $1.64 \pm 0.31^{\mathrm{b}}$ \\
\hline $3^{\text {rd }}$ & $8.65 \pm 0.22^{a}$ & $1.032 \pm 0.007^{\mathrm{a}}$ & $397.1 \pm 53.97^{\mathrm{a}}$ & $2.21 \pm 0.30^{\mathrm{a}}$ \\
\hline
\end{tabular}

$a \cdot b=$ mean values in the same column followed by different superscripts are significantly different at $(\mathrm{p}<\mathrm{o.o1})$

No. of measurement $=120$

Measurement are expressed as mean $\pm \mathrm{SD}$

$\mathrm{SPG}=$ specific gravity

$\mathrm{Vol}=$ volume of urine.

$1 \mathrm{st}=7 \mathrm{am}-3 \mathrm{pm}$.

$2 \mathrm{nd}=3 \mathrm{pm}-11 \mathrm{pm}$.

$3 \mathrm{rd}=11 \mathrm{pm}-7 \mathrm{am}$.

Table 2: Effect of time on Nubian goats urine electrolytes concentration.

\begin{tabular}{|c|c|c|c|c|c|c|}
\hline $\begin{array}{c}\text { parameters } \\
\text { Periods }\end{array}$ & $\begin{array}{c}\mathrm{Na} \\
\mathrm{m} \cdot \mathrm{mol} / \mathrm{L}\end{array}$ & $\mathrm{K} \mathrm{m} \cdot \mathrm{mol} / \mathrm{L}$ & $\mathrm{Ca} / \mathrm{mg} / \mathrm{L}$ & $\mathrm{Mg} / \mathrm{mg} / \mathrm{L}$ & Po4/mg/L & $\mathrm{Cl} / \mathrm{m} \cdot \mathrm{mol} / \mathrm{L}$ \\
\hline $1 \mathrm{st}$ & $173.70 \pm 5.79^{\mathrm{a}}$ & $6.05 \pm 0.14^{\mathrm{a}}$ & $8.43 \pm 0.32^{\mathrm{a}}$ & $152.38 \pm 13.41^{\mathrm{a}}$ & $4.58 \pm 0.19^{\mathrm{a}}$ & $102.85 \pm 4.53^{\mathrm{a}}$ \\
\hline $2 \mathrm{nd}$ & $171.83 \pm 5.14^{\mathrm{a}}$ & $6.01 \pm 0.13^{\mathrm{a}}$ & $8.29 \pm 0.32^{\mathrm{a}}$ & $148.73 \pm 12.10^{\mathrm{a}}$ & $4.55 \pm 0.19^{\mathrm{a}}$ & $102.30 \pm 3.20^{\mathrm{a}}$ \\
\hline 3rd & $163.50 \pm 14.74^{\mathrm{b}}$ & $6.04 \pm 0.16^{\mathrm{a}}$ & $8.25 \pm 0.31^{\mathrm{a}}$ & $148.30 \pm 13.69^{\mathrm{a}}$ & $4.53 \pm 0.15^{\mathrm{a}}$ & $104.20 \pm 3.31^{\mathrm{a}}$ \\
\hline
\end{tabular}

$a . b=$ mean values in the same column followed by different superscripts are significantly different at $(\mathrm{P}<0.05)$.

No. of measurement $=120$

Measurement are expressed as Mean \pm S.D.

$1 \mathrm{st}=7 \mathrm{am}-3 \mathrm{pm} . \quad 2 \mathrm{nd}=3 \mathrm{pm}-11 \mathrm{pm} . \quad 3 \mathrm{rd}=11 \mathrm{pm}-7 \mathrm{am}$. 
Table 3: Effect of time on Nubian goats urine electrolytes total excretory rate.

\begin{tabular}{|c|c|c|c|c|c|c|}
\hline $\begin{array}{c}\text { parameters } \\
\text { Periods }\end{array}$ & $\begin{array}{c}\mathrm{TE} \mathrm{Na} \\
\mathrm{m} . \mathrm{mol} / \mathrm{kg} / \mathrm{h}\end{array}$ & $\begin{array}{c}\mathrm{TE} \mathrm{k} \\
\mathrm{m} . \mathrm{mol} / \mathrm{kg} / \mathrm{h}\end{array}$ & $\begin{array}{c}\mathrm{TE} \mathrm{Cl} / \\
\mathrm{m} . \mathrm{mol} / \mathrm{kg} / \mathrm{h}\end{array}$ & $\begin{array}{c}\mathrm{TE} \mathrm{Mg} \\
\mathrm{mg} / \mathrm{kg} / \mathrm{h}\end{array}$ & $\begin{array}{c}\mathrm{TE} \mathrm{Po} 4 \\
\mathrm{mg} / \mathrm{kg} / \mathrm{h}\end{array}$ & $\begin{array}{c}\mathrm{TE} \mathrm{Ca} / \\
\mathrm{mg} / \mathrm{kg} / \mathrm{h}\end{array}$ \\
\hline $1 \mathrm{st}$ & $0.263 \pm 0.03$ & $0.009 \pm 0.003$ & $0.011 \pm 0.02$ & $0.221 \pm 0.022$ & $0.007 \pm 0.001$ & $0.011 \pm 0.003$ \\
\hline $2 \mathrm{nd}$ & $0.251 \pm 0.03$ & $0.009 \pm 0.002$ & $0.010 \pm 0.02$ & $0.217 \pm 0.025$ & $0.007 \pm 0.002$ & $0.010 \pm 0.003$ \\
\hline $3 \mathrm{rd}$ & $0.256 \pm 0.03$ & $0.009 \pm 0.003$ & $0.011 \pm 0.02$ & $0.217 \pm 0.023$ & $0.007 \pm .002$ & $0.011 \pm 0.002$ \\
\hline $\begin{array}{c}\text { Significance } \\
\text { level }\end{array}$ & $\mathrm{NS}$ & $\mathrm{NS}$ & $\mathrm{NS}$ & $\mathrm{NS}$ & $\mathrm{NS}$ & $\mathrm{NS}$ \\
\hline
\end{tabular}

$\mathrm{NS}=$ not significant

No. of measurement $=120$

Measurement are expressed as Mean \pm S.D.

$\mathrm{TE}=$ total excretory rate

$1 \mathrm{st}=7 \mathrm{am}-3 \mathrm{pm} . \quad 2 \mathrm{nd}=3 \mathrm{pm}-11 \mathrm{pm} . \quad 3 \mathrm{rd}=11 \mathrm{pm}-7 \mathrm{am}$.

Table 4: Effect of collection time on protein and non protein nitrogenous compounds indices of Nubian goats renal function.

\begin{tabular}{|c|c|c|c|c|c|c|}
\hline Parameters & $\begin{array}{c}\mathrm{CR}-\mathrm{Cl} \\
\mathrm{ml} / \mathrm{min} / \mathrm{kg}\end{array}$ & $\begin{array}{c}\text { Urea }-\mathrm{Cl} \\
\mathrm{ml} / \mathrm{min} / \mathrm{kg}\end{array}$ & $\begin{array}{c}\text { Urea } \\
\mathrm{mg} / \mathrm{ml}\end{array}$ & $\begin{array}{c}\text { Uric acid } \\
(\text { conc. }) \\
\mathrm{mg} / \mathrm{L}\end{array}$ & $\begin{array}{c}\text { Total Protein } \\
\text { concentration } \\
\mathrm{mg} / \mathrm{L}\end{array}$ & $\begin{array}{c}\mathrm{TE} \mathrm{Pr} \\
\mathrm{mg} / \mathrm{kg} / \mathrm{h}\end{array}$ \\
\hline Periods $^{\text {st }}$ & $3.74 \pm 0.6^{\mathrm{a}}$ & $1.85 \pm 0.40^{\mathrm{b}}$ & $18.33 \pm 0.09^{\mathrm{a}}$ & $200.75 \pm 36.9^{\mathrm{b}}$ & $9.15 \pm 0.33^{\mathrm{a}}$ & $0.014 \pm 0.000^{\mathrm{a}}$ \\
\hline $2^{\text {nd }}$ & $3.745 \pm 0.7^{\mathrm{a}}$ & $1.93 \pm 0.37^{\mathrm{b}}$ & $18.35 \pm 0.09^{\mathrm{a}}$ & $199.43 \pm 35.4^{\mathrm{b}}$ & $9.07 \pm 0.31^{\mathrm{a}}$ & $0.014 \pm 0.000^{\mathrm{a}}$ \\
\hline $3^{\text {rd }}$ & $3.80 \pm 0.5^{\mathrm{a}}$ & $2.21 \pm 0.39^{\mathrm{a}}$ & $18.06 \pm 0.08^{\mathrm{b}}$ & $210.15 \pm 33.7^{\mathrm{a}}$ & $9.02 \pm 0.27^{\mathrm{a}}$ & $0.019 \pm 0.000^{\mathrm{a}}$ \\
\hline
\end{tabular}

$\mathrm{ab}=$ means value in the same column followed by different superscripts are significantly different at $(\mathrm{P}<0.05)$.

No. of measurement $=120$.

Measurements are expressed as Mean \pm S.D.

Urea $-\mathrm{Cl}=$ urea clearance.

$\mathrm{CR}-\mathrm{Cl}=$ creatinine clearance.

TE.Pr. $=$ protein total excretory rate.

$1 \mathrm{st}=7 \mathrm{am}-3 \mathrm{pm} . \quad 2 \mathrm{nd}=3 \mathrm{pm}-11 \mathrm{pm} . \quad 3 \mathrm{rd}=11 \mathrm{pm}-7 \mathrm{am}$. 


\section{DISCUSSION}

A stable urine specific gravity was observed over the time, this finding is similar to the values previously reported by Barakat and El-Guindi (1968); Altman (1961); and Mathews (1999). The mean daily urine output and the urine out flow rate reported in the present work are within the normal range reported by other workers (Altman, 1961; Mathews, 1999) for goats.

The urine volume of the third collection period was significantly higher than that of the preceding periods. We suspect that at the $3^{\text {rd }}$ period the environmental temperature drops and the animals tend to rest, which most probably resulted in more urine formation.

The urine $\mathrm{pH}$ reported in this work was in accord with the values obtained by Altman (1961), Barakat and El-Guindi (1968), and Mathews (1999).

There were no significant differences in the urine concentration, or total excretory rate of total proteins, $\mathrm{Ca}, \mathrm{K}, \mathrm{Mg}, \mathrm{Po}_{4}$ and $\mathrm{Cl}$ among the collection periods. Similar findings were reported by Fleming et al. (1991) in dairy cattle and Garry et al. (1991) in sheep. Although urine concentrations of $\mathrm{Na}$ varied significantly with time, their total excretory rate remained stable over time. So this finding supports the opinion of Oken (1981) that the total excretory rate is the best measure which reflects the tubular handling of the solutes and also provides a clear picture for assessment of renal function in health and disease.

The values of urine concentration of $\mathrm{Na}$ in this study agreed well with the values obtained by Salwa et al. (2004) for Sudanese goats and were much lower than those obtained by Garry et al. (1991) in sheep. Higher values for TE-Na were reported by Garry et al. (1991) in sheep. This variation in urine $\mathrm{Na}$ concentration and TE-Na may be due to the variation in the $\mathrm{Na}$ proportion in the feed, as the goats in the present work were kept on a high diet $\mathrm{Na}$ proportion $(0.5 \%)$ compared with the $(0.2 \%)$ of the sheep of Garry et al. (1991).

The urine $\mathrm{K}$ concentration value in this work was similar to that recorded by Salwa et al. (2004) for Sudanese goats. However, higher values for urine K were obtained by Garry, et al. (1991) in sheep fed high dietary K. However, (TE) K for goats was much lower than that for sheep (Garry et al., 1991 and Rabinowitz et al., 1984). This discrepancy in urine $\mathrm{K}$ concentration and (TE) $\mathrm{K}$ can be attributed to $\mathrm{K}$ being unique among other substances in that it can be either reabsorbed or secreted, 
and consequently with a low in take of $\mathrm{K}$ there is no re-absorption and minimal secretion.

In this study the urine concentration of $\mathrm{Ca}$ agrees well with the values obtained by Salwa (2004) but is much lower than that reported by Barakat and El-Guindi (1968) for Egyptian goats. Moreover, the total (TE) $\mathrm{Ca}$ is lower than that reported by Altman (1963) for goats.

In the present study the urine $\mathrm{Mg}$ concentration was found to be comparable to the value of Salwa et al. (2004), and disagrees with that reported by Barakat and El-Guindi (1968).

Barakat and El-Guindi (1968) obtained higher urine $\mathrm{P}$ concentration than in the present work. The TE $\mathrm{PO}_{4}$ of this study is on line with the finding of Garry et al. (1991) in sheep. This low P excretion consolidates the finding of Osbaldiston and Moore (1971) that most $\mathrm{Po}_{4}$ excretion in ruminants occur in the gastrointestinal tract and the relationship of renal excretion to dietary intake and serum concentration is not clearly defined.

Although the urine $\mathrm{Cl}$ concentration in this study is lower than that obtained by Garry et al. (1991) for sheep the TE Cl agreed well with their finding.

Comparing the present results with those of previously reports showed a great variation in the excretion of the different electrolytes. Such a variation is probably acceptable because of variation in the environmental conditions, sex, species, activities of the animal, diet and many other factors which are known to affect the renal handling of the electrolytes.

The urine urea and uric acid concentrations of the third collection period differed from that of the other periods, although they were within the range reported by Altman (1961). Urea clearance varied over time indicating that urea clearance is not a reliable method for characterization of renal function (Bickhard and Dungelhoef, 1994).

The endogenous creatinine clearance reported in this work remained stable over time indicating a stable renal function resulting from the stable experimental conditions. It is similar to the value found by Bove and Joya (1979) in dogs for endogenous creatinine, and to inulin clearance in sheep (Valtonen et al., 1982). However, lower values were obtained by other researchers for inulin clearance in sheep (Garry et al., 1990; Bickhard and Dugelhof, 1994), and in goats (Brown et al., 1990). This variation may be attributed to many factors including dietary protein level, age, body weight, muscle mass and physical activity (Valtonen et al., 1982). Also variation in the analytical methods for 
creatinine measurement in serum and urine may preclude proper interlaboratory comparison as stated by Brown et al. (1990).

It is concluded that in healthy goats, under stable condition, their kidney excretory function does not vary significantly over time, similar results were reported by Kokkonen et al. (2001). The latter authors found that there was no circadian variation of plasma atrial natriuretic peptide in the goat plasma to which these results could be attributed. So eight hours urine collection period seems to be valid for studying goats renal indices under the Sudan conditions.

\section{REFERENCES}

Altman, L.P. (1961): Blood and other body fluids, 1st ed. Pub. Federation of American Societies for Experimental Biology. U.S.A.

Barkat, M.Z. and El-Guindi, M.M. (1968): Biochemical analysis of normal goat urine. Zent. VetA.Vol. 15: 60-8.

Bickhardt, K. and Dungelhoef, R. (1994): Clinical studies of kidney function in sheep, and reference values of healthy animals. Dtsch Tieravztl Wochenschr 101: 463-466.

Bove, K.C. and Joyce, T. (1979): Clinical evaluation of glomerular function 24-hours creatinine clearance in dogs. J. Am. Vet. Med. Assoc. Vol. 174: 488-491.

Brown, S.A.; Groves, C.; Barasanti, J.A. and Finco, D.R. (1990): Determination of excretion of inulin, creatinine, sodium sulfanilate and phenolsulfonphthalein to assess renal function in goats. Am. J. Vet. Res., Vol. 51: 581-586.

Bosnes, W. and Toussky, H.H. (1945): Determination of creatinine in serum and urine. J. of Bio. Vol. 1:158.

Fleming, S.A.; Hunt, E.L.; Riviere, J.E. and Anderson, K.L. (1991): Renal clearance and fractional excretion of electrolytes over four 6-hour periods in cattle. Am. J. Vet. Res. Vol. 52: 5-8.

Garry, F.; Chew, D.J.; Rings, D.M.; Tarr, M.J. and Hoffsis, G.F. (1991): Renal excretion of creatinine, electrolytes, protein, and enzymes in healthy sheep. Am. J. Vet.Res, Vol. 51: 414-419.

Gomez, K.A. and Gomez, A.A. (1984): Statistical procedure for agricultural research, $2^{\text {nd }} \mathrm{ed}$. Wily and Sons, Inc. New York.

Guyton, A.C. and Hall, J.E. (2000): Text Book of Medical Physiology, $10^{\text {th }}$ ed. W.B. Saunders Company. Philadelphia, London, New York, Sydney, Toront. 
Kokkonen, U.M.; Riskila, P.; Roihankorpi, M.T. and Soveri, T. (2001): Circadian variation of plasma atrial natriuretic peptide, cortisol and fluid balance in the goat.Acta.Physiol.Scand.Vol. 171: 1-8.

Mathews, J.G. (1999): Disease of the goat, $2^{\text {nd }}$, Pub. Blackwell Science PP. 331.

Norbert, W.T. (1982): Fundamentals of clinical chemistry, W.B. Saunders Company, Philadelphiapp: 919-920.

Oken, D.E. (1981): On the differential diagnosis of acute renal failure. J. Med. Vol. 71: 916-920.

Osbaldiston, G.W. and Moore, W.E. (1971): Renal function in cattle. J. Am. Vet. Med. Assoc. Vol. 159: 292-301.

RabinoWitz, L.; Sasrason, R.L. and Yamauchi, H. (1984): Sheep renal potassium excretion: efferent Kaliuretic regulatory factors. Am. J. Physiol. Vol. 247: 520-526.

Salwa, M.E.; Ali, K.M.S; Samia, H.A. and Majid, A.M. (2004): Physical and biochemical contents of camel, cattle, goat and human urine. J. of Anim. and Vet. Adv. Vol.3: 587-590.

Trinder, P. (1960): Colorimetric micro-determination of calcium. Analyst. Vol. 85: 889-894.

Valtonen, M.H.; Uasi-Rauva, A. and Eriksson, L. (1982): The effect of protein deprivation on the validity of creatinine and urea in evaluation of renal function. Experimental study in the goat. Scand. J. Clin. Lab.Vol.42: 507 - 512.

Varley, H. (1967): Practical Chemical Biochemistry Vol. 1 Oxford University Press London.

Vogel, (1982): Text book of qualitative inorganic analysis. $3^{\text {rd }}$ edition. 